\title{
REMEDIAL AND CORRECTIVE FEEDBACK STRATEGIES FOR IMPROVING STUDENTS' ENGLISH LANGUAGE PROFICIENCY
}

\author{
Paul Kharlo L. Maawa \\ University of the Philippines Los Baños, Philippines \\ Email:plmaawa@up.edu.ph \\ Ruth Ortega-Dela Cruz \\ University of the Philippines Los Baños, Philippines \\ Email: raortegadelacruz@up.edu.ph
}

DOI : 10.26858/ijole.v1i1.7794

\begin{abstract}
The study used descriptive research design to evaluate the use of remedial and corrective feedback strategies in improving students' English language proficiency. Purposive sampling of English teachers and secondary students were surveyed and interviewed to address the research objectives. Descriptive statistics were used to analyse the data gathered using researcher-made instrument. Findings show that peer support program and handling students' behaviour problems were the most commonly used remedial strategies by the English teachers whereas, explicit correction, clarification request, recast, elicitation and paralinguistic signal were the commonly used corrective feedback strategies in teaching English. Cross-examination in the students' grades indicates positive effect of remedial and corrective feedback strategies in improving the English language proficiency of the students. The teachers know well how to use corrective feedback strategies although some might not be aware that they are using it. Corrective feedback should also come first since it can be incorporated in the remedial teaching strategy while the teacher is conducting remedial classes. This will further enhance their teaching while providing concrete ways to help improve the students' English language proficiency.
\end{abstract}

Keywords: corrective feedback strategies, English language, proficiency, remedial instruction

\section{INTRODUCTION}

Since it is clearly understandable that every child is significantly different in terms of intelligence, it is also vivid that there are varieties in learning which forms the high achievers and low achievers. Some learners might be able to adopt easily to the typical classroom instruction, but some considerable number of students cannot.

Under the trend of globalization, English has become the international language that links the whole world together. For individual, having adequate English competence is not only the basic requirement for pursuing careers or job promotions, but also a means of obtaining latest knowledge and expanding horizons.
English competence of Filipino people has great influence to their competitive advantage. Sadly, a number of students studying the language find a hard time learning it. In this case, there is a need to provide low-achieving students with more chances to reinforce the basic knowledge of English so they can meet minimum academic standards. English remedial instruction is effective and beneficial to low achievers.

Successful remedial instruction is a type of clinical teaching. It is a spiral process of assessment- instruction-reassessment. The subjects are targeted at low achievement learners, or under-prepared students. After the teacher diagnoses the student's learning difficulties, a remedial 
course will be designed in accordance with student's need. After doing so, the teacher takes initiative in offering remedial instruction, and an evaluation will be conducted during and after the implementation of remedial instruction to examine the actual effectiveness of the course.

Alongside the conduct of remedial practices is giving feedback to students. According to Ellis (2009), the role of feedback has a place in most theories of second language (L2) learning and language pedagogy. In both behaviourist and cognitive theories of L2 learning, feedback is seen as contributing to language learning. In both structural and communicative approaches to language teaching, feedback is viewed as a means of fostering learner motivation and ensuring linguistic accuracy. This study draws on second language acquisition (SLA) and language pedagogy in order to examine a number of controversial issues relating to one type of feedback - corrective feedback.

Corrective feedback constitutes one type of negative feedback. It takes the form of a response to a learner utterance containing a linguistic error. The response is another- initiated repair and can consist of (1) an indication that an error has been committed, (2) provision of the correct target language form, (3) metalinguistic information about the nature of the error, or any combination of these (Ellis, Loewen, and Erlam, 2006).

To know the remedial practices and corrective feedback strategies of teachers as well as finding how they correlate to students English language proficiency should crucially be revealed. This is significant so these students can compensate for the insufficient learning in previous academic settings that can lead to gaining skills necessary to complete the academic programs successfully.

According to Fatemipour, Safivand and Sanavi (2010), giving learners corrective feedback is one of the most timeconsuming tasks that teachers experience in their classes. As learners submit and the teacher receives the written outputs, teachers begin correcting them with all the strategies they know. However, most educators are not mastering the art of corrective feedback strategies from lack of acceptable materials to be used as standards in giving them. More so, another missing ingredients are that giving such feedbacks are less reliable when learner's weaknesses are not diagnosed beforehand and remedial practices often do not follow.

The teacher has to select both the particular strategy to use in response to the learner error and the specific linguistic devices for realizing that strategy. This calls for considerable pragmatic and pragma linguistic competence, and it is likely that teachers respond intuitively to particular errors committed by individual students rather than knowingly in accordance with some predetermined errorcorrection policy. This may explain two general characteristics of teachers' error correction practices - they are imprecise and inconsistent. Imprecision is evident in the fact that teachers use the same overt behaviour (e.g., "repetition") both to indicate that an error has been made and to reinforce a correct response (Lyster, 1998 in Morris, 2005). Nystrom (1983 in Morris, 2005) also commented that "teachers typically are unable to sort through the feedback options available to them and arrive at an appropriate response." Inconsistency arises when teachers respond variably to the same error made by different students in the same class, correcting some students and ignoring others. Such inconsistency is not necessarily detrimental, however, for, as Allwright (1975 in Ellis, 2009) has pointed out, it may reflect teachers' attempts to cater for individual differences among the students.

Remedial practices and corrective feedback strategies come hand in hand to deliver the curriculum effectively. With the aid of each, an educator is given an opportunity to maximize student learning. 


\section{Objectives of the Study}

The study aims to evaluate the effect of teachers' remedial and corrective feedback strategies on the students English language proficiency. It specifically (1) described the existing practice of English teachers' remedial and corrective feedback strategies in conducting the remedial instruction (2) analysed the difference in the evaluation on the use of remedial and corrective feedback strategies between the teachers' and students' perceptions; and (3) examined the English Language Proficiency of students before and after the use of remedial and corrective feedback strategies by English teachers.

\section{METHODOLOGY}

This section presents the research methodology which includes research design, the respondents, of the study, the sampling technique, the instrumentation as well as the statistical treatment.

\section{Research Design}

The study used descriptive research design to evaluate the use of remedial and corrective feedback strategies in improving students' English language proficiency.

\section{Respondents of the Study}

The respondents of this study include seven English teachers and 80 high school students of Maryhill College Lucena City for the Academic Year 2017- 2018. In particular, the student-respondents were 12 grade 7,10 grade 8 and 58 grade 10 students.

\section{Sampling Technique}

The respondents were chosen through purposive sampling based on the following criteria that the teachers were (1) teaching English subject in the Secondary Level, and (2) conducting remedial classes and do corrective feedback strategies as part of classroom instruction. Likewise, the students were divided into two groups, one group that received remedial and corrective feedback strategies, and one that did not.
This was pre-distinguished by the researcher through questionnaire. The first group members were chosen through the following criteria: (1) enrolled in the Maryhill College- Basic Education Department both for the academic year 2016-2017 and 2017-2018, (2) enrolled in English subject at Secondary Level for two consecutive years, (3) referred by the teacher as one who needs to enrol to remedial class with a low grade in English and (4) received remedial classes and corrective feedback strategies from the same English Teachers. On the other hand, The second group members were chosen through the following criteria: (1) enrolled in the Maryhill College- Basic Education Department both for the academic year 2016-2017 and 2017-2018, (2) enrolled in English subject at Secondary Level for two consecutive years, (3) received low grade in English in the previous school year; and (4) did not attend and experience remedial classes and corrective feedback strategies from the same English Teachers.

\section{Instrumentation}

To gather needed information for the study, a researcher-made survey questionnaire on remedial and corrective feedback strategies was used. The indicators for these sets of questions were based from the claims of Ellis et. al. (2006) and Bureau of Education and Hong Kong Government (2014). Part I describes the remedial strategies in terms of Individualized Education Program, Peer Support Program, Reward Scheme and Handling Students' Behaviour Problems. Part I B of the questionnaire describes the use of corrective feedback strategies by the teachers in terms of Recast, Repetition, Clarification Request, Explicit Correction, Elicitation and Paralinguistic Signal. This questionnaire for the teachers also asked for some basic information such as the frequency of their use of remedial and corrective feedback strategies in teaching English subject, as well as their age, sex and years of teaching experience. 
Another set of questionnaire was administered to the student respondents. Part I determines their grade in English for two quarters and other basic information like their grade level and sex. Part II assesses the remedial and corrective feedback strategies used by their teachers. It was paraphrased to layman language so to assure comprehension from the students.

Meanwhile, the grades from the English Teachers served as the instrument to confirm the English Language Proficiency of students before and after the remedial and corrective feedback strategies.

\section{Statistical Treatment}

Descriptive statistics such as frequencies, means and percentages were used to analyse the data gathered for the study.

\section{RESULTS AND DISCUSSIONS}

Table 1. Profile of the Teacher Respondents
This section presents the detailed results of the study.

Table 1 shows the profile of teacher respondents in terms of age, sex, number of years as an English teacher, and frequency of their remedial classes. Majority of them is women and 71 per cent are between 2029 years old. Out of seven English teachers, two of them have been teaching for less than a year. Four of them taught for one to three years and only one has been teaching for more than five years. Three of them are conducting remedial classes for only one to three times a month. Two or 29 per cent of them are conducting the remedial classes four to six times a month and another two or 29 per cent for seven to nine times a month. As per interview, the teachers are holding these classes right after the residential classes throughout the day.

\begin{tabular}{lcc}
\hline Profile & $\boldsymbol{f}$ & $\boldsymbol{\%}$ \\
\hline Age & 5 & 71 \\
$20-29$ years old & & \\
$30-39$ years old & 1 & 14 \\
$40-49$ years old & 1 & 14 \\
$\mathrm{n}$ & 7 & 100 \\
Sex & & \\
Female & 6 & 86 \\
Male & 1 & 14 \\
$\mathrm{n}$ & 7 & 100 \\
Years of teaching experience & & \\
Less than a year & 2 & 29 \\
$1-3$ years & 4 & 57 \\
More than 5 years & 1 & 14 \\
$\mathrm{n}$ & 7 & 100 \\
Frequency of remedial classes & & \\
$1-3$ times a month & 3 & 43 \\
$4-6$ times a month & 2 & 29 \\
$7-9$ times a month & 2 & 29 \\
n
\end{tabular}

In terms of the profile of the student-respondents, majority of them are from grade 10, having the age of 14 years old and above. There were no grade 9 
students however. This is because there were no conduction of remedial classes in grade 9 .

Table 2 presents the remedial strategies used by the English teachers as confirmed by the student respondents. In the area of Peer Support Program, the students' responses affirm the results of their teachers' responses. All the statements from both respondents resulted to the same sequence of descriptions: Always, always, often, often, and often. This means that teachers always train up students who perform better, always allow cooperation to take place in the classroom, and often conduct remedial activities where they can associate with each other, hold meetings regularly with other English teachers, and uses the strategy in higher grade level. This indicates that in general, peer support program is often used by the English teachers. Truly, peer support provides a dynamic nurturing process in a noncompetitive environment that promotes independence and self-actualization. Providing peer support may foster pride, fulfilment, and continuity in the mentor (Plamondon and CCGHR, 2007).

On the other hand, the responses of the students in the areas of Individualized Education Program or IEP, Reward Scheme, and in Handling Students' Behavioural Problems do not agree with the teachers' responses in terms of their frequency of application. The strategy is often used by teachers but is seldom used according to student responses. According to some students during informal interview, the teachers do not always have time to conduct the classes in a one-to-one basis since they are loaded with hectic schedules. This oppose the significant requirement of IEP from the Ontario Ministry of Education (2000) that says an IEP should also have written plan describing the special education program and/or services required Table 2. Remedial Strategies used by English Teachers by a particular student. It was also distinct that the teachers seldom meet parents to talk with them about their condition in class and seldom allot ample time for scheduling remedial classes.

In terms of Reward Scheme, according to the students, it turns out that the teachers just tell them that they could have such reward but do not materialize them afterwards. Some teachers still believe in the power of external motivation just like how often the English teachers of Maryhill College do this strategy. Deci and Ryan (1985 in Promberger and Marteau, 2013) cited that extrinsic motivation provided by an incentive can reduce intrinsic motivation: that is, attaching a price to a task that was initially enjoyable can make it less enjoyable.

In terms of Handling Students' Behavioural Problems, the teachers' responses on the use of the strategy do not conform to students' responses. However, it is agreed that teachers always observe the performance of the student and his behaviour in groups. Teachers, having always used this strategy, might also root from the claims of Walters and Frei (2007) who called classroom as the experimental lab of the child. They believe that because children spend a major part of their formative years in school, it becomes vital to examine the roles of classroom management and discipline as an important dynamic in student experience and success. More so, from the interviews, teachers reveal that they get frustrated easily if they fail to discipline their students. This is basically parallel to the findings of the Teacher Support Network and Family Lives Behaviour (2013) survey that disruptive student behaviour is a frustration for many teachers where 70 per cent of teachers told them they had considered quitting the profession over poor behaviour. 


\begin{tabular}{|c|c|c|c|c|}
\hline & \multicolumn{2}{|c|}{$\begin{array}{c}\text { Teacher } \\
\text { Evaluation }\end{array}$} & \multicolumn{2}{|c|}{$\begin{array}{c}\text { Student } \\
\text { Evaluation }\end{array}$} \\
\hline & $\overline{\mathbf{x}}$ & DA & $\overline{\mathbf{x}}$ & DA \\
\hline A.Individualized Education Program & & & & \\
\hline 1. overcomes student learning difficulties & 3.29 & Always & 2.56 & Often \\
\hline $\begin{array}{l}\text { 2. conducts the remedial program individually after } \\
\text { class }\end{array}$ & 2.43 & Seldom & 1.58 & Never \\
\hline 3. holds meetings regularly with the parents & 2.29 & Seldom & 1.79 & Seldom \\
\hline $\begin{array}{l}\text { 4. makes sure to have a different schedule per } \\
\text { student }\end{array}$ & 2.71 & Often & 2.10 & Seldom \\
\hline $\begin{array}{l}\text { 5. varies teaching techniques and strategies per } \\
\text { student }\end{array}$ & 3.29 & Always & 2.19 & Seldom \\
\hline $\begin{array}{l}\text { Grand Weighted Mean } \\
\text { B. Peer Support Program }\end{array}$ & 2.80 & Often & 2.04 & Seldom \\
\hline $\begin{array}{l}\text { 6. trains up students who perform better to become } \\
\text { "little teachers" }\end{array}$ & 3.43 & Always & 2.48 & Always \\
\hline $\begin{array}{l}\text { 7. allows cooperation to take place in the remedial } \\
\text { program }\end{array}$ & 3.29 & Always & 2.86 & Always \\
\hline $\begin{array}{l}\text { 8. conducts remedial activities where they can } \\
\text { associate with those who do not need remedial } \\
\text { teaching }\end{array}$ & 3.00 & Often & 2.04 & Often \\
\hline $\begin{array}{l}\text { 9. holds meetings regularly with other English } \\
\text { teachers to gather materials for teaching }\end{array}$ & 3.14 & Often & 2.34 & Often \\
\hline $\begin{array}{l}\text { 10. uses this strategy to students of higher grade } \\
\text { level }\end{array}$ & 2.86 & Often & 2.53 & Often \\
\hline $\begin{array}{l}\text { Grand Weighted Mean } \\
\text { C. Reward Scheme }\end{array}$ & 3.14 & Often & 2.45 & Often \\
\hline 11. sets clear and achievable targets for rewards & 3.43 & Always & 2.84 & Often \\
\hline $\begin{array}{l}\text { 12. invites parents to help students improve their } \\
\text { work and give them rewards }\end{array}$ & 2.29 & Seldom & 2.14 & Seldom \\
\hline $\begin{array}{l}\text { 13. reviews and revises the reward scheme } \\
\text { regularly }\end{array}$ & 2.86 & Often & 2.49 & Seldom \\
\hline $\begin{array}{l}\text { 14. rewards remedial students who graduate from } \\
\text { the remedial class }\end{array}$ & 2.71 & Often & 1.90 & Seldom \\
\hline 15. gives negative forms of reinforcement & 1.71 & Never & 2.88 & Often \\
\hline Grand Weighted Mean & 2.60 & Often & 2.45 & Seldom \\
\hline D. Handling Student's Behaviour Problems & & & & \\
\hline $\begin{array}{l}\text { 16. always observes the performance of students in } \\
\text { class and their behaviour in groups }\end{array}$ & 3.86 & Always & 3.53 & Always \\
\hline $\begin{array}{l}\text { 17. establishes close relationship with students to } \\
\text { develop their mutual trust } \\
\text { 18. does not change deviant behaviour of students }\end{array}$ & 3.57 & Always & 3.05 & Often \\
\hline all at once & 2.57 & Often & 2.26 & Seldom \\
\hline $\begin{array}{l}\text { 19. keeps contact with parents to find out the causes } \\
\text { of behaviour problems of students }\end{array}$ & 3.00 & Often & 1.98 & Seldom \\
\hline $\begin{array}{l}\text { 20. helps students understand the effect of their } \\
\text { behaviour }\end{array}$ & 3.57 & Always & 3.11 & Often \\
\hline Grand Weighted Mean & 3.31 & Always & 2.79 & Often \\
\hline
\end{tabular}

Range: (4) 3.25-4.00- Always; (3) 2.50-3.24- Often; (2) 1.74-2.49-Seldom; (1) 1.00-1.74-Never 
Table 3 presents the corrective feedback strategies used by English teachers as again validated by the students. Findings show that in the areas of Explicit Correction, Repetition, and Paralinguistic Signal, the students' responses attest the results of their teachers' responses. In particular, both of the respondents rated explicit correction and paralinguistic signal as frequently applied by English teachers. While repetition as rarely applied. Specifically, teachers never use sarcasm and based from the structured interviews, they indicated that this is because they believe this may cause negative impact to the furtherance of student learning.

For English teachers, Paralinguistic Signal as a corrective feedback strategy is time-consuming. It calls for the teacher to be able to write clear and accurate explanations for a variety of errors (Azizi, Behjat and Sorahi, 2014).

Contrarily, there is a minor discrepancy in the perceived frequency of application of some corrective feedback strategies such as Clarification Request, Recast, and Elicitation.

Basically, in terms of Clarification Request, the students approve the claims and even crack jokes imitating some of the clarification request corrective feedback strategies used by their teachers. On the same hand, the reason why teachers consider to use this always might root from the claims of cognitive linguist Michael Long (2011 in Bing-jie, 2016), who proposed interaction hypothesis and advocates for the benefits of clarification request as it provides especially advantageous opportunities for explicit learning. Likewise, the clarification request, in particular, are crucial points at which explicit and implicit learning combine in optimal ways (Bing-jie, 2016).

Based from the interview, the students perceive that Recast is the best strategy for them since it makes them realise themselves that they were wrong, so they could avoid in the future. More positive results were reported by Ellis (2009) who found that recasts elicited a high rate of successful uptake (71.6 per cent) in English as a Second Language (ESL) classrooms.

Furthermore, English teachers stated that it is much more complicated to use Elicitation since it adjusts to the most appropriate form of corrective feedback, therefore combines some of the known corrective feedback they know.

The high frequency of the feedback opposes the sociolinguistic views of Lochtman (2018) which does not necessarily allow grammatical mistakes but practically permits the reality of variation.

Table 3. Corrective Feedback Strategies used by English Teachers

\begin{tabular}{llcccc}
\hline Strategies & \multicolumn{2}{c}{$\begin{array}{c}\text { Teacher } \\
\text { Evaluation }\end{array}$} & $\begin{array}{c}\text { Student } \\
\text { Evaluation }\end{array}$ \\
& $\overline{\mathbf{x}}$ & DA & $\overline{\mathbf{x}}$ & DA \\
\hline $\begin{array}{l}\text { A.Explicit Correction } \\
\begin{array}{l}\text { 1. clearly indicates that the student's utterance was } \\
\text { incorrect, and provides them with the correct form. }\end{array}\end{array}$ & 3.29 & Always & 3.20 & Often \\
$\begin{array}{l}\text { 2. uses some phrases to correct the student such as } \\
\text { "oh you mean" or "you should say" }\end{array}$ & 3.43 & Always & 2.95 & Often \\
$\begin{array}{l}\text { 3. directly corrects the student orally in grammar } \\
\text { especially on subject-verb agreement }\end{array}$ & 3.00 & Often & 3.18 & Often \\
$\begin{array}{l}\text { 4. corrects the student with exact information } \\
\text { wrongfully said }\end{array}$ & 3.29 & Always & 2.93 & Often \\
$\begin{array}{l}\text { 5. abruptly halts the students for wrong } \\
\text { pronunciation }\end{array}$ & 2.57 & Often & 3.01 & Often \\
\hline
\end{tabular}




\begin{tabular}{|c|c|c|c|c|}
\hline Grand Weighted Mean & 3.11 & Often & 3.05 & Often \\
\hline \multicolumn{5}{|l|}{ B. Repetition } \\
\hline $\begin{array}{l}\text { 6. repeats the students' error and change intonation } \\
\text { to draw their attention to it }\end{array}$ & 2.71 & Often & 2.84 & Often \\
\hline 7. repeats wrong subject verb agreement answers & 3.00 & Often & 2.83 & Often \\
\hline $\begin{array}{l}\text { 8. directs the students to change wrong answers by } \\
\text { repeating the word and giving them a frown }\end{array}$ & 2.00 & Seldom & 2.64 & Often \\
\hline $\begin{array}{l}\text { 9. provides sarcasm after repeating the wrong } \\
\text { answer made }\end{array}$ & 1.29 & Never & 2.38 & Seldom \\
\hline $\begin{array}{l}\text { 10. gives the correct answer to students after } \\
\text { repeating the wrong response given }\end{array}$ & 1.71 & Never & 2.56 & Often \\
\hline Grand Weighted Mean & 2.00 & Seldom & 2.47 & Seldom \\
\hline \multicolumn{5}{|l|}{ C. Clarification Request } \\
\hline $\begin{array}{l}\text { 11. indicates to the students that I did not } \\
\text { understand what they said }\end{array}$ & 3.14 & Often & 2.90 & Often \\
\hline $\begin{array}{l}\text { 12. uses "sorry?" when misheard a response from } \\
\text { the student. }\end{array}$ & 3.43 & Always & 3.18 & Often \\
\hline $\begin{array}{l}\text { 13. says "pardon me?" if misheard or do not } \\
\text { accept the student's answer. }\end{array}$ & 3.29 & Always & 2.76 & Often \\
\hline $\begin{array}{l}\text { 14. clarifies unethical responses by means of saying } \\
\text { "Excuse me?" }\end{array}$ & 3.29 & Always & 2.93 & Often \\
\hline $\begin{array}{l}\text { 15. completes the student responses by asking } \\
\text { questions }\end{array}$ & 3.14 & Often & 2.98 & Often \\
\hline Grand Weighted Mean & 3.29 & Always & 2.98 & Often \\
\hline \multicolumn{5}{|l|}{ D. Recast } \\
\hline $\begin{array}{l}\text { 16. repeats the students' utterance and provide the } \\
\text { correct answer without pointing out that they are } \\
\text { incorrect. }\end{array}$ & 3.29 & Always & 2.95 & Often \\
\hline 17. returns wrong terms used in conversations & 3.43 & Always & 2.73 & Often \\
\hline $\begin{array}{l}\text { 18. gives sensitive repeating responses to students' } \\
\text { grammatical errors }\end{array}$ & 3.29 & Always & 3.03 & Often \\
\hline 19. utters correctly mispronounced words & 3.43 & Always & 3.01 & Often \\
\hline $\begin{array}{l}\text { 20. correct lexical words wrongfully used by the } \\
\text { students in asking permissions }\end{array}$ & 3.29 & Always & 2.83 & Often \\
\hline $\begin{array}{l}\text { Grand Weighted Mean } \\
\text { E. Elicitation }\end{array}$ & 3.34 & Always & 2.83 & Often \\
\hline $\begin{array}{l}\text { 21. directly elicits the correct form from the student } \\
\text { by asking questions }\end{array}$ & 3.43 & Always & 3.39 & Always \\
\hline $\begin{array}{l}\text { 22. gives students chance to correct their answers } \\
\text { through using at least three paraphrasing of } \\
\text { questions given }\end{array}$ & 3.57 & Always & 3.04 & Often \\
\hline $\begin{array}{l}\text { 23. gets appropriate responses from literary } \\
\text { mistakes }\end{array}$ & 3.29 & Always & 2.90 & Often \\
\hline $\begin{array}{l}\text { 24. requires the students to answer in a series of yes } \\
\text { or no questions }\end{array}$ & 3.00 & Often & 2.88 & Often \\
\hline $\begin{array}{l}\text { 25. uses a lot of techniques combined when dealing } \\
\text { with wrong responses }\end{array}$ & 3.14 & Often & 3.10 & Often \\
\hline $\begin{array}{l}\text { Grand Weighted Mean } \\
\text { F. Paralinguistic Signal }\end{array}$ & 3.29 & Always & 3.06 & Often \\
\hline
\end{tabular}




\begin{tabular}{|c|c|c|c|c|}
\hline $\begin{array}{l}\text { 26. provides related comment to the students' } \\
\text { response without telling them the correct answer }\end{array}$ & 2.71 & Often & 2.99 & Often \\
\hline $\begin{array}{l}\text { 27. states rule of grammar when the student posted } \\
\text { wrong response }\end{array}$ & 3.43 & Always & 2.99 & Often \\
\hline $\begin{array}{l}\text { 28. asks question with regard to wrong statement } \\
\text { without rewarding the answer }\end{array}$ & 3.00 & Often & 2.84 & Often \\
\hline $\begin{array}{l}\text { 29. mentions appropriate vowel or consonant sound } \\
\text { in English language so the students can apply it } \\
\text { themselves }\end{array}$ & 3.57 & Always & 2.90 & Often \\
\hline $\begin{array}{l}\text { 30. corrects misspoken words with appropriate } \\
\text { layman comment }\end{array}$ & 3.14 & Often & 3.14 & Often \\
\hline Grand Weighted Mean & 3.17 & Often & 2.96 & Often \\
\hline
\end{tabular}

Range: (4) 3.25-4.00- Always; (3) 2.50-3.24- Often; (2) 1.74-2.49-Seldom; (1) 1.00-1.74-Never

Cross-examination in the students' grades in Table 4 reveals significant improvement in the performance of the students in English subject. As compared in the previous semester, where there was one student who got a grade of 75 and below. Twenty-six per cent got a grade of 76-80. While, 33 per cent got the grades between 81-85 and 86-90. And only two per cent got a grade of 91 and above. But in the succeeding semester, 32 per cent of them got the grade from 81-85, 22 per cent got 86-90. Overall, it increased up to 18 per cent who got a grade of 91 and above. This signifies the positive impact of remedial and corrective feedback strategies in improving the English language proficiency of the students.

Table 4. Students' English Language Proficiency Improvement through Remedial and Corrective Feedback Strategies by English Teachers

\begin{tabular}{lllll}
\hline Grade in English & \multicolumn{2}{c}{ Before } & \multicolumn{2}{c}{ After } \\
& \multicolumn{1}{c}{$f$} & \multicolumn{1}{c}{$f$} & $\%$ \\
\hline 75 and below & 1 & 1 & 0 & 0 \\
$76-80$ & 21 & 26 & 22 & 28 \\
$81-85$ & 28 & 35 & 26 & 32 \\
$86-90$ & 28 & 35 & 18 & 22 \\
91 and above & 2 & 3 & 14 & 18 \\
$\mathrm{n}$ & 80 & 100 & 80 & 100 \\
\hline
\end{tabular}

\section{CONCLUSIONS}

The study elucidates the importance of incorporating remedial and corrective feedback strategies in the teaching of English as second language. The teachers know well how to use corrective feedback strategies although some might not be aware that they are using it. There are several loopholes in remedial strategies like scheduling, meeting up with parents and guardian, and other significant factors like formulating reward schemes. In corrective feedback strategies, the teachers only have to differentiate what one particular strategy is distinct than the other. Also, corrective feedback should come first since it can be incorporated in the remedial teaching strategy while the teacher is conducting remedial classes.

While the study provides significant information useful for the English teachers, there are still some areas that need further investigation. Therefore, further studies should be conducted in other localities, 
schools and regions to further validate the result of this study. Other factors such as social context and background may be probed to see if these have strong impact in the remedial practices and corrective feedback received by the student respondents. Future researches could base upon the results of the study to formulate an enhancement program using appropriate instructional materials not intended solely for students who are taking remedial classes but most importantly for English teachers. This will further equip them in their teaching by providing concrete ways to help improve the students' English language proficiency.

\section{REFERENCES}

Azizi, M., Behjat, F., and Sorahi, M. A. (2014). Effect of Metalinguistic Teacher Corrective Feedback on Writing Performance of Iranian EFL learners. International Journal of Language and Linguistics International Journal of Language and Linguistics. Special Issue: Innovations in Foreign Language Teaching, 2(6), 54-63. https://doi.org/10.11648/j.ijll.s.201402 0601.18

Bing-jie, G.U. (2016). Is Recast the Most Effective Type of Corrective Feedback?-Under Cognitive and Sociolinguistic Approach. Sino-US English Teaching, 13(4). doi: 10.17265/1539-8072/2016.04.006

Bureau of Education and Hong Kong Government Retrieved 9 February 2014 from http: //hkgovt.boe.com

Ellis, R. (2009). Corrective Feedback and Teacher Development. L2 Journal, 1(1). https://doi.org/10.5070/12.v1i1.9054

Ellis, R., Loewen, S., and Erlam, R. (2006). Implicit and Explicit Corrective Feedback and the Acquisition of L2 Grammar. Studies in Second Language Acquisition, 28(02). https://doi.org/10.1017/s02722631060
60141

Fatemipour, H., Safivand, A., and Sanavi, R. V. (2010). Corrective Feedback Strategies and Learners' and Teachers' Preferences, (November), 6571-6579.

Fatemipour, Safivand and Sanavi (2010). Corrective feedback strategies and learners' and teachers' preferences. ICERI Proceedings, p.6571-6579. Retrieved from academia.edu

Lochtman, K. (2018). Prescription and Tradition in Language. Retrieved from https://books.google.com.ph/books?id=ES hoDQAAQBAJandpg=PA89andlpg $=\mathrm{P}$ A89anddq $=$ Lochtman+(2012)andsourc $\mathrm{e}=$ blandots=ruw28akDxOandsig=z7mj3Pa7sDs0PdKLfizhY5uBxYandhl= enandsa $=\mathrm{Xandved}=2 \mathrm{ah}$

UKEwjckcnpxsXfAhWOMd4KHfeNBPE Q6AEwAHoECAkQAQ\#v=onepagean $\mathrm{dq}=$ Lochtmanper cent20(2012) andf=false

Ontario Ministry of Education. (2000). Individual Education Plans. Retrieved from

http://www.oafccd.com/documents/IEPsta ndards.pdf

Morris, F. (2005). Child-to-child interaction and corrective feedback in a computer mediated L2 class. Language Learning and Technology, 9(1), 29-45. Retrieved from http://llt.msu.edu/vol1num1/morris/

Plamondon, K. and CCGHR Capacity Building Task Group: Sub-group on Mentorship. (2007). Module One: An Introduction to Mentorship. Retrieved from

https://www.ccghr.ca/wpcontent/uploads/2013/05/Mentoring_M odule1_An-Introduction_e.pdf

Promberger, M., and Marteau, T. (2013). When do financial incentives reduce intrinsic motivation? Comparing behaviours studied in psychological and economic literatures. Health Psychology, 32(9), 950-957. doi: 10.1037/a0032727

Teacher Support Network and Family Lives Behaviour. (2013). Managing 
Student Behaviour. Retrieved from https://www.educationsupportpartnersh ip.org.uk/

sites/default/files/resources/teacher_suppor t_net Work__behaviour practical_

guide_-_black_and_white__jun_2013_0.pdf

Walters, J., and Frei, S. (2007). Managing Classroom Behaviour and Discipline Professional Development for Successful Classrooms. Retrieved from https://books.google.com.ph/books/abo ut/Managing_Classroom_Behavior_an d_Discipli.html?id=zOKwgwg09UCandredir_esc=y 